Sains Malaysiana 46(1)(2017): 43-50

http://dx.doi.org/10.17576/jsm-2017-4601-06

\title{
Biodegradation of Tapis Crude Oil Using Consortium of Bacteria and Fungi: Optimization of Crude Oil Concentration and Duration of Incubation by Response Surface Methodology
}

(Biodegradasi Minyak Mentah Tapis Menggunakan Konsortium Bakteria dan Kulat: Pengoptimuman Kepekatan Minyak Mentah dan Tempoh Pengeraman dengan Kaedah Gerak Balas Permukaan)

\author{
AINON HAMZAH*, VidYAH MANIKAN \& NUR AIN FATHIHA ABD AZIZ
}

\section{ABSTRACT}

Response surface analysis was conducted to optimize the concentrations of Tapis crude oil and duration of incubation in order to achieve optimal microbial growth and crude oil biodegradation. Central Composite Rotatable Design (CCRD) was employed, where the design contained 13 experimental runs with different combinations of incubation time and crude oil concentration. The cultures containing mineral salt medium (MSM) with varying crude oil concentrations were incubated at $30^{\circ} \mathrm{C}$, pH6.5 with $150 \mathrm{rpm}$ agitation for $120-336 \mathrm{~h}$. The inoculum contained a consortium of previously identified as oil degrading bacteria and fungi, namely Pseudomonas aeruginosa UKMP-14T, Acinetobacter baumannii UKMP-12T and Trichoderma sp. UKMP-1M and UKMP-2M. The analysis showed the duration of incubation plays a significant role $(p<0.05)$ in affecting the bacterial growth and percentage of total petroleum hydrocarbon (TPH) biodegradation, meanwhile concentrations of Tapis crude oil has insignificant effect on the responses. Interaction of the two variables was found to be significant in affecting all the three responses, namely bacterial population, fungal biomass and percentage of TPH biodegradation. It was predicted through the CCRD that the percentage of biodegradation can be optimized to reach $86 \%$ on the 270 th $h$ when $5 \%(v / v)$ crude oil was used. This predicted value was verified to be achievable and reproducible through validation experiments.

Keywords: Biodegradation; crude oil; response surface methodology

ABSTRAK

Analisis gerak balas permukaan digunakan untuk mengoptimumkan kepekatan minyak mentah Tapis (yang ditemui dalam perairan Malaysia) dan tempoh pengeraman untuk mencapai pertumbuhan mikrob dan biodegradasi minyak mentah yang optimum. Reka Bentuk Gubahan Memusat Berputar (CCRD) telah digunakan, dengan 13 larian reka bentuk eksperimen kombinasi kepekatan minyak mentah dan tempoh pengeraman yang berbeza. Kultur yang ditumbuhkan dalam medium garam mineral (MSM) dengan kepekatan minyak mentah yang berbeza dieram pada suhu $30^{\circ} \mathrm{C}$ dan pH6.5 dengan kadar goncangan 150 psm bagi tempoh eraman 120-336 jam. Inokulum yang digunakan mengandungi konsortium bakteria dan kulat pengurai minyak yang telah dikenal pasti dalam kajian sebelumnya, iaitu Pseudomonas aeruginosa UKMP14T, Acinetobacter baumannii UKMP-12T dan Trichoderma sp. UKMP-1M dan UKMP-2M. Hasil analisis menunjukkan tempoh masa eraman memainkan peranan yang signifikan $(p<0.05)$ dalam mempengaruhi pertumbuhan bakteria dan peratus biodegradasi, manakala kepekatan minyak mentah Tapis tidak memainkan peranan yang signifikan. Interaksi antara dua pemboleh ubah juga didapati mempunyai kesan yang signifikan ke atas ketiga-tiga gerak balas yang dikaji, iaitu populasi bakteria, biojisim kulat dan peratus biodegradasi minyak mentah. Berdasarkan perisian CCRD, peratus biodegradasi yang optimum, iaitu $86 \%$ boleh dicapai pada jam yang ke-270 apabila 5\% (v/v) minyak mentah digunakan. Jangkaan kombinasi optimum ini telah diuji dan disahkan melalui eksperimen.

Kata kunci: Analisis gerak balas permukaan; biodegradasi; minyak mentah

\section{INTRODUCTION}

Bacteria are known as the most active agents in petroleum degradation and they work as primary degraders in the oil spilled environment (Brooijmans et al. 2009). Many studies have shown that bacteria can degrade various types of hydrocarbon. One such example is Acinetobacter sp. which is capable of utilizing n-alkanes of chain length $\mathrm{C}_{10}-\mathrm{C}_{40}$ as a sole source of carbon (Throne-Holst et al. 2007).
Adebusoye et al. (2007) reported nine bacterial strains, namely, Pseudomonas fluorescens, P. aeruginosa, Bacillus subtilis, Bacillus sp. Alcaligenes sp., Acinetobacter lwoffi, Flavobacterium sp., Micrococcus roseus and Corynebacterium sp. isolated from the polluted stream in Lagos, Nigeria which could degrade crude oil. Other organisms including fungal genera, namely, Amorphoteca, Neosartorya, Talaromyces and Graphium and yeast 
genera, namely, Candida, Yarrowia and Pichia isolated from petroleum-contaminated soil were also proven to be potential organisms for hydrocarbon degradation (Chaillan et al. 2004).

Biodegradation of hydrocarbon is influenced by several factors apart from the type of microorganisms being employed. Physical and environmental factors such as nutrients, $\mathrm{pH}$, temperature, moisture, oxygen availability, soil conditions, agitation and concentration of polluted substrate are essential to attain optimal growth where the microbes will decompose hydrocarbons effectively (Bento et al. 2005). Optimization of bioremediation requires considerable time when parameters are optimized according to the conventional 'one factor at a time' (OFAT) technique (Mohajeri et al. 2010). Current preferred alternative method to replace OFAT is response surface methodology (RSM) where a number of parameters are simultaneously optimized based on statistical assumptions and estimations. This method is useful to create a quantitative model of the synergistic effects of conditions on crude oil biodegradation (Mitsika et al. 2013).

Study by Mohajeri et al. (2011) using central composite design and RSM to optimize four variables which include amount of oil, bacterial inoculum, nitrogen and phosphorus for the removal of n-alkanes of weathered crude oil in coastal sediments showed an increase in oil concentration will decrease $\mathrm{n}$-alkanes removal. The maximum n-alkanes removal was achieved at $4.8 \times 10^{6}$ cells of bacterial consortium. Agarry et al. (2012) also proved the predicted maximum kerosene removal using RSM modeling was reliable and powerful tool in optimization various variables such as NPK fertilizer, Tween 80 and hydrogen peroxide for maximum kerosene bioremediation.

Various local isolates of bacteria and fungi isolated from Malaysian soil and water have been shown to be good oil decomposers (Ainon et al. 2012). Bacillus subtilis UKMP-10T, Stenotrophomonas maltophilia UKMP-11T, Acinetobacter baumannii UKMP-12T, Acinetobacter jejuni UKMP-13T and Pseudomonas aeruginosa UKMP$14 \mathrm{~T}$ are among the best isolates that exhibit excellent oil decomposition properties, which, in our preliminary works were found to attain $100 \%$ hydrocarbon degradation when $1 \%(\mathrm{v} / \mathrm{v})$ crude oil is provided as the sole carbon source (Ainon et al. 2014, 2013). P. aeruginosa UKMP-14T and A. baumannii UKMP-12T were selected as best oil degraders since total petroleum hydrocarbon (TPH) degradation of $1 \%(\mathrm{v} / \mathrm{v})$ of Tapis crude oil were $85.2 \%$ and $76.2 \%$, respectively (Ainon et al 2013). For fungi, Trichoderma sp. UKMP-1M and UKMP-2M, the TPH degradation of $1 \%$ $(\mathrm{v} / \mathrm{v})$ Khefji crude oil obtained from these isolates were
$39.52 \%$ and $54.83 \%$, respectively (Ainon et al. 2012). Instead of single culture, these organisms can also be used in mixed cultures in order to increase the rate of petroleum biodegradation (Thenmozhi et al. 2011).

In order to obtain maximum biodegradation of crude oil by using combination of bacteria and fungi as microbial consortium, this study was carried out to determine the capability of this consortium in degrading optimum concentrations of Tapis crude oil and duration of incubation for maximum TPH degradation using RSM as tool for reliable modeling.

\section{MATERIALS AND METHODS}

\section{STANDARD CULTURE OF INOCULUM}

Stock cultures of Pseudomonas aeruginosa UKMP-14T, Acinetobacter baumannii UKMP-12T, Trichoderma sp. UKMP-1M and UKMP-2M were obtained from the School of Biosciences and Biotechnology, Universiti Kebangsaan Malaysia (UKM). Preparation of standard cultures of inoculums for P. aeruginosa UKMP-14T and A. baumannii UKMP-12T were carried out according to method by Ainon et al. (2010). The final concentrations of the cells are $10^{8} \mathrm{cfu} / \mathrm{mL}$ and this concentration was used as starter inoculums for subsequent experiment.

The standard inoculums for fungal Trichoderma sp. UKMP-1M and UKMP-2M were done according to Ainon et al. (2012). Briefly, the final concentration of spores of $1 \times$ spores $/ \mathrm{mL}$ was transferred into a $250 \mathrm{~mL}$ Erlenmeyer flask containing mineral salt medium (MSM) and $3 \%(\mathrm{v} / \mathrm{v})$ glucose. The cultures were then incubated for $48 \mathrm{~h}$ at $30^{\circ} \mathrm{C}$ with $200 \mathrm{rpm}$ agitation. The cultures were centrifuged and the cells were washed 3 times with sterilised distilled water to remove the remaining glucose. The resulting cultures were then used as standard inoculums for next experiment.

The microbial consortium was prepared by mixing the standard cultures of $P$. aeruginosa UKMP-14T, $A$. baumannii UKMP-12T, Trichoderma sp. UKMP-1M and UKMP-2M at a ratio of $1: 1: 1: 1(\mathrm{v} / \mathrm{v})$. This inoculum was used in the next experiment. Mineral salt medium (MSM) was used throughout the experiment as previously described in Ainon et al. (2012).

\section{EXPERIMENTAL DESIGN}

The constant variables were temperature, $\mathrm{pH}$ and agitation which were set at $30^{\circ} \mathrm{C}, 6.5$ and $150 \mathrm{rpm}$, respectively. The range of parameters is shown in Table 1 . The results were presented as the average value of duplicates flasks.

TABLE 1. Range of tested crude oil concentration and duration of incubation

\begin{tabular}{lccc}
\hline Factor & Minimum value & Centre point & Maximum value \\
\hline A: Crude oil concentration (\%) & 2.0 & 3.5 & 5.0 \\
B: Duration of incubation (h) & 120 & 228 & 336 \\
\hline
\end{tabular}


Central composite rotatable design (CCRD) was employed in this study, where a set of thirteen runs with six centre point replications using Design Expert 8.0.4.1 software shown in Table 2 . The responses, namely number of bacteria $\left(\log _{10} \mathrm{CFU} / \mathrm{mL}\right)$, biomass of fungi $(\mathrm{g} / \mathrm{L})$ and percentage total petroleum hydrocarcon, (TPH) were analysed using the respective variances (ANOVA). Based on ANOVA results, a suitable polynomial was chosen for each response to regress the data and then a suitable equation to summarize the behaviour of the system was generated.

\section{BACTERIA ENUMERATION AND FUNGAL BIOMASS DETERMINATION}

The number of bacteria in MSM was enumerated by spread plate method. The bacteria suspension was serially diluted in a normal saline solution then cultured on plates which were then incubated at $37^{\circ} \mathrm{C}$ for $24 \mathrm{~h}$.

Fungal biomass was determined as dry weight. After incubation, the MSM $(50 \mathrm{~mL})$ was mixed with $50 \mathrm{~mL}$ chloroform in order to dissolve the crude oil and then dried in the fume hood. The aqueous phase containing fungal cells was filterated using Whatman no.4 filter paper and oven dried at $60^{\circ} \mathrm{C}$ for $72 \mathrm{~h}$ to obtain the dry biomass of fungal cells.

\section{HYDROCARBON DEGRADATION}

The hydrocarbon extraction and gas chromatography analysis were done according to method by Ainon et al. $(2012,2010)$. Chloroform was used for oil extraction from the medium. The percentage of total petroleum hydrocarbon (TPH) was used as indicator of hydrocarbon degradation.

\section{RESULTS AND DISCUSSION}

\section{EFFECT OF CRUDE OIL CONCENTRATION - INCUBATION TIME ON THE GROWTH OF BACTERIA}

The results showed that the highest number of bacteria was obtained from run number 3 , where $\log _{10} \mathrm{CFU} / \mathrm{mL}$ was 14.45 (Table 2) with crude oil concentration $3.5 \%$ at incubation time $228 \mathrm{~h}$. Meanwhile, the lowest growth was observed in run number 4 , with $\log _{10} \mathrm{CFU} / \mathrm{mL}$ was 9.54 with $5 \%$ crude oil concentration at $120 \mathrm{~h}$. The ratio of maximum to minimum growth is 1.51 , which indicates that power transformation is not needed to analyse this set of data statistically. This was further confirmed by referring to the software-generated normal plot of residuals. Based on sequential model sum of squares, quadratic model was found to be suitable to analyse this data, where the probability $(\mathrm{P}>\mathrm{F})$ value for this model was 0.0268 . This value indicates that confidence level for quadratic model is 97.32\%. Lack-of-fit test for this model scored a $P>F$ value of 0.0526 , indicating that this model is suitable to regress the data without being biased by normal scattering. $\mathrm{R}^{2}$ value for this model was reasonable with a score of 0.8474 . Upon choosing quadratic equation as the fitted model, ANOVA was carried out to study the effect of variables on bacterial propagation. This model with F-value 7.78 implies it is significant. From the analysis, it was found that duration of incubation (B) as well as the interaction of crude oil concentration and duration of incubation $(\mathrm{AB})$ are significant factors affecting the growth of bacteria studied, A. baumannii UKMP-12T and $P$. aeruginosa UKMP-14T. ANOVA result for this response is shown in Table 3.

Using this model, the following regression equation was generated by the software, in which, the coefficient of each factor indicates the relative effect of the factor:

$$
\begin{aligned}
\mathrm{Y}= & 13.84+0.41 \mathrm{~A}+1.32 \mathrm{~B}- \\
& 0.33 \mathrm{~A}^{2}-1.29 \mathrm{~B}^{2}+1.5 \mathrm{AB},
\end{aligned}
$$

where $\mathrm{Y}$ is $\log _{10} \mathrm{CFU} / \mathrm{mL}$; $\mathrm{A}$ is the concentration of crude oil; and B is the duration of incubation.

Based on the above equation, it can be seen that the relative effect of interaction between concentration of crude oil and duration of incubation is larger than the effect of its parent factors. Figure 1(a) shows the response surface plot and the associated contour plot which can be used to visualize

TABLE 2. Effect of crude oil concentration - incubation time on the growth of bacteria, fungal biomass and hydrocarbon degradation by Design Expert software

\begin{tabular}{cccccc}
\hline Run & $\begin{array}{c}\text { Crude oil } \\
\text { concentration }(\%)\end{array}$ & $\begin{array}{c}\text { Duration of } \\
\text { incubation }(\mathrm{h})\end{array}$ & $\begin{array}{c}\text { No. of bacteria } \\
(\mathrm{CFU} / \mathrm{mL})\end{array}$ & $\begin{array}{c}\text { Biomass of fungi } \\
(\mathrm{g} / \mathrm{L})\end{array}$ & $\begin{array}{c}\text { Hydrocarbon } \\
\text { degradation }(\%)\end{array}$ \\
\hline 1 & 3.50 & 380.74 & 14.38 & 0.039 & 66.10 \\
2 & 5.62 & 228.00 & 14.38 & 0.326 & 80.00 \\
3 & 3.50 & 228.00 & 14.45 & 0.122 & 74.18 \\
4 & 5.00 & 120.00 & 9.54 & 0.097 & 15.87 \\
5 & 3.50 & 228.00 & 13.99 & 0.760 & 53.23 \\
6 & 2.00 & 120.00 & 11.57 & 0.112 & 55.80 \\
7 & 5.00 & 336.00 & 14.42 & 0.453 & 63.63 \\
8 & 3.50 & 228.00 & 13.29 & 0.870 & 57.70 \\
9 & 3.50 & 228.00 & 13.28 & 0.750 & 33.34 \\
10 & 3.50 & 228.00 & 14.17 & 0.260 & 43.25 \\
11 & 2.00 & 336.00 & 10.45 & 0.042 & 19.00 \\
12 & 1.38 & 228.00 & 13.42 & 0.157 & 86.46 \\
13 & 3.50 & 75.26 & 9.58 & 0.093 & 12.92 \\
\hline
\end{tabular}


TABLE 3. ANOVA for growth of bacteria $\left(\log _{10} \mathrm{CFU} / \mathrm{mL}\right)$

\begin{tabular}{lccccc}
\hline Source & Sum of squares & Degree of freedom & Mean & F value & Prob>F \\
\hline Model & 36.01 & 5 & 7.20 & 7.78 & $0.0089^{*}$ \\
$\mathrm{~A}$ & 1.36 & 1 & 1.36 & 1.47 & 0.2651 \\
$\mathrm{~B}$ & 13.91 & 1 & 13.91 & 15.01 & $0.0061^{*}$ \\
$\mathrm{~A}^{2}$ & 0.75 & 1 & 0.75 & 0.81 & 0.3969 \\
$\mathrm{~B}^{2}$ & 11.56 & 1 & 11.56 & 12.48 & $0.0096^{*}$ \\
$\mathrm{AB}$ & 9.00 & 1 & 9.00 & 9.72 & $0.0169^{*}$ \\
Residuals & 6.48 & 7 & 0.93 & & 0.0526 \\
Lack of fit & 5.36 & 3 & 1.79 & 6.39 & \\
Pure error & 1.12 & 4 & 0.28 & & \\
Cor total & 42.50 & 12 & & & \\
\hline
\end{tabular}

$* p<0.05$ is significant
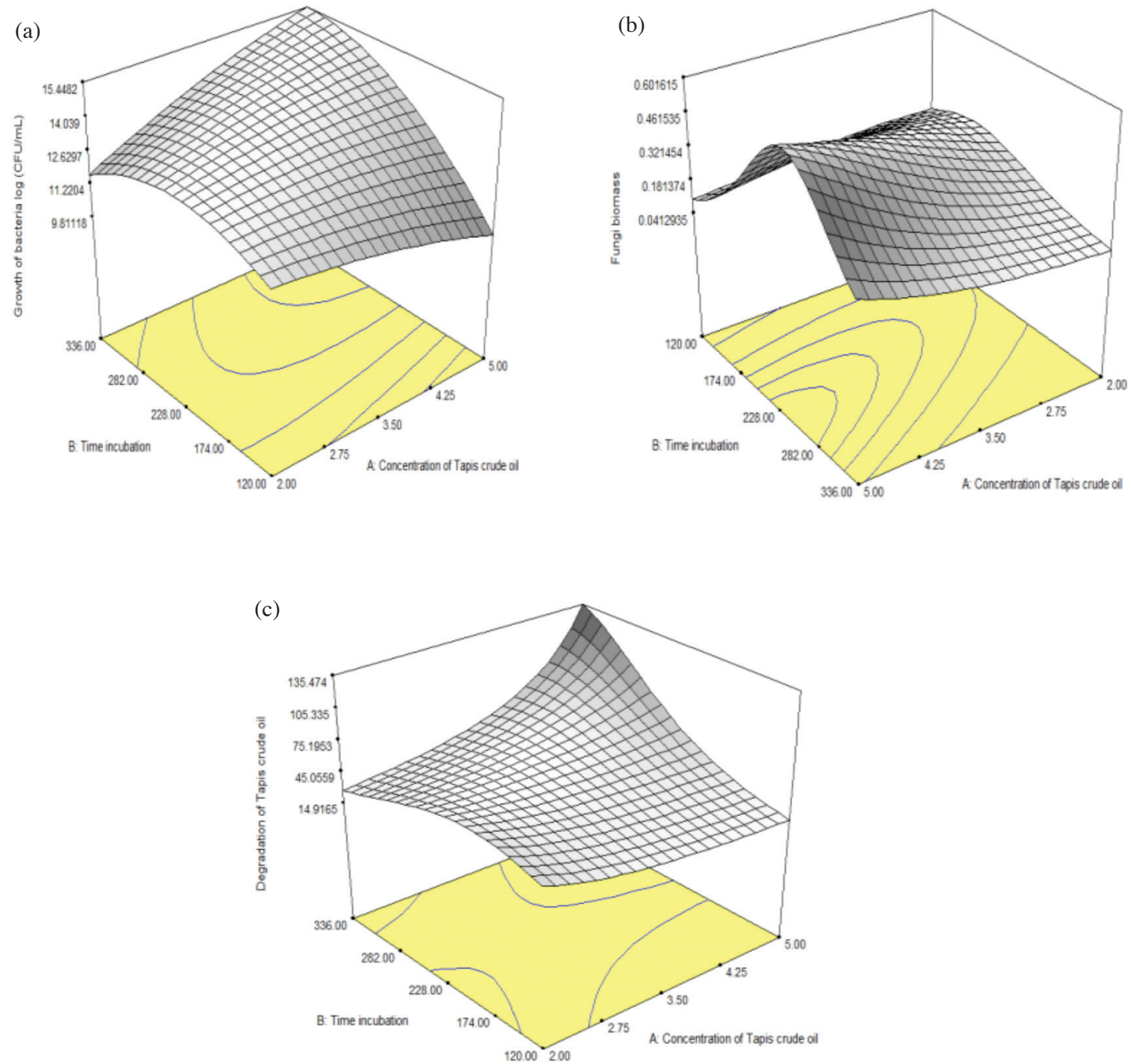

FIGURE 1. Response surface plots indicating the effect of interaction between variables on responses: (a) effect interaction of crude oil concentration-duration of incubation on growth of bacteria, (b) effect interaction of crude oil concentrationduration of incubation on growth of fungi, (c) effect interaction of crude oil concentration-duration of incubation on the percentage of crude oil biodegradation 
the effect of the above mentioned interaction on $\log _{10} \mathrm{CFU} /$ $\mathrm{mL}$. The number of bacteria $\left(\log _{10} \mathrm{CFU} / \mathrm{mL}\right)$ increased as the concentration of crude oil and duration of incubation are increased simultaneously. The growth of $A$. baumannii UKMP-12T and $P$. aeruginosa UKMP-14T is affected at high concentrations of crude oil up at $5 \%(\mathrm{v} / \mathrm{v})$. The growth was reduced by $4 \log$ cycles compared to concentration at $3.5 \%$. According to Changyi et al. (2009), when crude oil in the environment reached a definite concentration it would have toxic effect on microorganisms, because the strain could not tolerate the high concentration of crude oil, which would inhibit the normal microbial growth to dramatically reduce the hydrocarbon degradation rate. The inhibitory concentration varies with oil composition (Mohajeri et al. 2011). Alkanes of intermediates chain length $\left(\mathrm{C}_{10}-\mathrm{C}_{24}\right)$ are often degraded immediately, while long chain alkanes are resistant to microbial degradation (Ijaha \& Antaib 2003). According to Haines et al. (2003) the decline in bacterial growth upon increased oil concentration was due to oxygen scarcity. The result also showed that extension of incubation period (336 h) did not increase in TPH degradation.

\section{EFFECT OF CRUDE OIL CONCENTRATION - INCUBATION TIME ON GROWTH OF FUNGI}

The highest amount of biomass produced by Trichoderma sp. UKMP-1M and UKMP-2M was $0.87 \mathrm{~g} / \mathrm{L}$, obtained in run number 8 , whereas the lowest amount $(0.039 \mathrm{~g} / \mathrm{L})$ was in run number 1 . Ratio of maximum to minimum was 22.3, indicating the need for power transformation in order to obtain a suitable dataset to be analysed statistically. Thus, a power transformation of inverse square root was applied to the data. Sequential sum of squares showed that quadratic equation is the suitable model to explain the behaviour of this response, where it scored a significant $\mathrm{P}>\mathrm{F}$ value for a model, insignificant $\mathrm{P}>\mathrm{F}$ value in lack-of-fit test and a satisfactory $\mathrm{R}^{2}$ value of 0.8287 . Next, ANOVA was carried out using this model and the results are presented in Table 4. The final equations for the response of fungal growth in terms of the factors are given as follows:

$$
\begin{aligned}
= & 1.64-0.53 \mathrm{~A}+0.34 \mathrm{~B}+0.25 \mathrm{~A}^{2}+ \\
& 1.26 \mathrm{~B}^{2}-0.90 \mathrm{AB},
\end{aligned}
$$

where $\mathrm{Y}$ is the fungal biomass $(\mathrm{g} / \mathrm{L})$; $\mathrm{A}$ is the concentration of crude oil; and $\mathrm{B}$ is the duration of incubation.

From Table 4, it can be seen that the interaction between concentration of crude oil and duration of incubation (AB) is the only significant factor affecting the growth of fungi Trichoderma sp. UKMP-1M and UKMP-2M. The negative coefficient of this interaction in the above equation (-0.90 $\mathrm{AB})$ showed that this factor exerts a significant negative effect on response. However, conversion of the response to original scale from the transformed scale results in a positive relationship. Thus, interaction of $\mathrm{AB}$ promotes the growth of fungi Trichoderma sp. UKMP-1M and UKMP-2M Figure 1(b) showed the 3-dimensional and contour plots of this interaction in original scale which aid to comprehend the pattern and effect of factor $\mathrm{AB}$ on fungal growth.

The surface plot in Figure 1(b) shows that an increase in fungal biomass occur approximately at 250th $\mathrm{h}$ of incubation when crude oil concentration is maximum $(5 \%$ $\mathrm{v} / \mathrm{v})$. This indicates that higher fungal biomass may be obtained when crude oil concentration is further increased beyond $5 \%(\mathrm{v} / \mathrm{v})$. However, in contrast to the growth of bacteria, the fungal growth was found to be decreasing as the duration of incubation is extended beyond $250 \mathrm{~h}$. This may be due to lack of carbon source after prolonged time of incubation. Therefore, an increase in crude oil concentration will result in longer log and stationary phases and thus delay the decline phase. This will consequently lead to acquisition of higher fungal biomass which proportionally results in better oil degradation. Such technique is believed to result in better biodegradation as the individual strains in the consortium adapted to the new environment and reach growth equivalence (Sharma \& Rehman 2009).

\section{EFFECT OF CRUDE OIL CONCENTRATION-DURATION OF INCUBATION ON THE CRUDE OIL DEGRADATION}

The highest percentage of crude oil degradation was obtained in run number 12 , where $86.46 \%$ of the crude oil was degraded. Opposed to this, lowest biodegradation occurred in run number 13 , where only $12.92 \%$ of the crude oil was degraded. Ratio of maximum to minimum was 6.69 , showing that power transformation step is not

TABLE 4. ANOVA for growth of fungi $(\mathrm{g} / \mathrm{L})$

\begin{tabular}{lccccc}
\hline Source & Sum of squares & Degree of freedom & Mean $^{2}$ & F value & P $>$ F \\
\hline Model & 17.58 & 5 & 3.52 & 6.77 & $0.0130^{*}$ \\
$\mathrm{~A}$ & 2.27 & 1 & 2.27 & 4.38 & 0.0748 \\
$\mathrm{~B}$ & 0.90 & 1 & 0.90 & 1.74 & 0.2284 \\
$\mathrm{~A}^{2}$ & 0.42 & 1 & 0.42 & 0.81 & 0.3985 \\
$\mathrm{~B}^{2}$ & 11.09 & 1 & 11.09 & 21.35 & $0.0024^{*}$ \\
$\mathrm{AB}$ & 3.27 & 1 & 3.27 & 6.30 & $0.0404^{*}$ \\
Residuals & 3.63 & 7 & 0.52 & & 0.6058 \\
Lack of fit & 1.24 & 3 & 0.41 & 0.69 & \\
Pure error & 2.40 & 4 & 0.60 & & \\
Cor total & 21.22 & 12 & & & \\
\hline
\end{tabular}

$* p<0.05$ is significant 
necessary. However, a power transformation to inverse square root was employed to rearrange the pattern of data distribution in order to be suitable for polinomial based regression analysis. Similar to the other two responses discussed above, sequential model sum of squares $(\mathrm{P}>\mathrm{F}$ 0.025), lack-of-fit test ( $P>F 0.0916)$ and $R^{2}(0.7907)$ values showed that a quadratic equation is the fitted model to analyse the data. Upon selecting the suitable model, ANOVA was carried out and the results are presented in Table 5.

The regression equation for this response in terms of the factors is given by:

$$
\begin{aligned}
= & 0.14+(2.39 \mathrm{E}-3) \mathrm{A}-0.031 \mathrm{~B}-(8.724 \mathrm{E}-3) \mathrm{A}^{2} \\
& +0.037 \mathrm{~B}^{2}-0.055 \mathrm{AB},
\end{aligned}
$$

where $\mathrm{Y}$ is the crude oil biodegradation $(\%)$; $\mathrm{A}$ is the concentration of crude oil; and $\mathrm{B}$ is the duration of incubation.

Similar to the first response discussed above $\left(\log _{10}\right.$ $\mathrm{CFU} / \mathrm{mL}$ ), the percentage of crude oil degradation is affected significantly by the duration of incubation and the interaction between crude oil concentration and duration of incubation. The regression equation for this response showed that factor $\mathrm{B}$ and also the interaction of $\mathrm{AB}$ exerted a negative effect on the inverse square root of percentage of biodegradation. This indicates that, when converted to original scale from the transformed scale, factor $\mathrm{B}$ and $\mathrm{AB}$ exerts positive effect on the response. The relationship between factor $\mathrm{AB}$ and the response can be seen clearly in the 3-dimensional plot shown in Figure 2(c). Based on the figure, it can be observed that percentage of biodegradation increases as crude oil concentration and duration of incubation are increased. This pattern is in a good agreement with the other two responses, especially bacterial growth where simultaneous increase of factor $\mathrm{A}$ and $\mathrm{B}$ results in better propagation. However, fungal growth is suppressed by extended incubation period when $5 \%(\mathrm{v} / \mathrm{v})$ of crude oil is supplied.

Overall, all the three responses studied are affected significantly in positive manner by the interaction between crude oil concentration and duration of incubation. In order to determine the optimal point of both parameters where simultaneous good bacterial and fungal growth occur to promote efficient biodegradation, software based numerical optimization was carried out.

Many researchers have studied degradation of hydrocarbon using mixed cultures of bacteria. The advantage of using mixed culture rather than pure isolate is their metabolic versatility that could enhanced the hydrocarbon degradation (Bao et al. 2012; Ghazali et al. 2004; Moneke \& Nwangwu 2011). For example, study done Muthuswamy et al. (2008) showed by using bacterial consortium which consists of Bacillus sp., Corynebacterium sp. and two Pseudomonas sp., the degradation of $1 \%$ crude oil at $30^{\circ} \mathrm{C}$ after incubation at 25 days was higher by $77 \%$ as compared to the individual strains ranged from $69-41 \%$. Very few researchers have been carried out using mixed culture of bacteria and fungi for hydrocarbon degradation. By using compatible mixed populations with overall broad enzymatic capacities, the degradation will be much faster and completed. It has been demonstrated that hydrocarbon-utilizing bacteria have a preference for long chain aliphatic hydrocarbons. Straight chain n-alkanes containing 10-18 carbon atoms are assimilated with the greatest frequency and rapidity. Branched chain alkanes, monocyclic substrates and aromatic compounds are seldom utilized. There is a specificity of the utilization of individual hydrocarbons by different microorganisms depending upon the range of enzyme produced by them and the molecular conjugation of the hydrocarbon. The initial intracellular attack of organic pollutants is an oxidative process and the activation as well as incorporation of oxygen is the enzymatic key reaction catalyzed by oxygenases and peroxidases (Das \& Chandran 2011). In this study, the rotation at $150 \mathrm{rpm}$ is to ensure the organisms have sufficient oxygen for the oxidation reaction could occur with complete biodegradation. This is because hydrocarbon degradation is highly oxidative process in which both aeration and agitation are required for maximal degradation (Sharma \& Pant 2001).

TABLE 5. ANOVA for percentage of crude oil biodegradation

\begin{tabular}{lccccc}
\hline Source & Sum of squares & Degree of freedom & Mean $^{2}$ & F value & P $>$ F \\
\hline Model & 0.031 & 5 & $6.150 \mathrm{E}-3$ & 5.29 & $0.0250^{*}$ \\
$\mathrm{~A}$ & $4.570 \mathrm{E}-5$ & 1 & $4.570 \mathrm{E}-5$ & 0.04 & 0.8485 \\
$\mathrm{~B}$ & $7.788 \mathrm{E}-3$ & 1 & $7.788 \mathrm{E}-3$ & 6.70 & $0.0360^{*}$ \\
$\mathrm{~A}^{2}$ & $5.295 \mathrm{E}-4$ & 1 & $5.295 \mathrm{E}-4$ & 0.46 & 0.5214 \\
$\mathrm{~B}^{2}$ & $9.390 \mathrm{E}-3$ & 1 & $9.390 \mathrm{E}-3$ & 8.08 & 0.0250 \\
$\mathrm{AB}$ & 0.012 & 1 & 0.012 & 10.52 & $0.0142^{*}$ \\
Residuals & $8.139 \mathrm{E}-3$ & 7 & $1.163 \mathrm{E}-3$ & 4.45 & 0.0916 \\
Lack of fit & $6.263 \mathrm{E}-3$ & 3 & $2.088 \mathrm{E}-3$ & & \\
Pure error & $1.876 \mathrm{E}-3$ & 4 & $4.690 \mathrm{E}-4$ & & \\
Cor total & 0.039 & 12 & & & \\
\hline
\end{tabular}

$p<0.05$ is significant 
TABLE 6. Numerical optimization of parameters for enhanced biodegradation

\begin{tabular}{llccc}
\hline Constraint & Goal & Lower limit & Upper limit & Solution \\
\hline Crude oil concentration & In range & 2 & 5 & 5.00 \\
Duration of incubation & In range & 120 & 336 & 270.09 \\
Log CFU/mL & Maximum & 9.54 & 14.45 & 14.82 \\
Fungal biomass & Maximum & 0.039 & 0.87 & 0.57 \\
degradation & Maximum & 12.92 & 86.46 & 86.46 \\
Desirability & & & & 0.979 \\
\hline
\end{tabular}

\section{DETERMINATION OF OPTIMAL CRUDE OIL CONCENTRATION AND DURATION OF INCUBATION FOR ENHANCED BIODEGRADATION}

The criteria set for optimization and the predicted optimal points for factors A and B are presented in Table 6. This result suggested optimal combination was predicted to result in $\log _{10} \mathrm{CFU} / \mathrm{mL}$ of $14.82,0.57 \mathrm{~g} / \mathrm{L}$ fungal biomass and $86.46 \%$ biodegradation. Even though the percentage of biodegradation predicted for this combination is the same as that obtained in the experimental run number 12, the absolute amount of crude oil that will be degraded is higher. In run number $12,86.46 \%$ of $1.38 \%(\mathrm{v} / \mathrm{v})$ crude oil was degraded. In a $50 \mathrm{~mL}$ culture, $1.38 \%$ (v/v) crude oil corresponds to $0.69 \mathrm{~mL}$. In contrast to this, the predicted optimal combination contains $5 \%(\mathrm{v} / \mathrm{v})$ oil of which $86.46 \%$ is predicted to be degraded. This implies that 2.16 $\mathrm{mL}$ of crude oil will be degraded. Thus, the suggested optimal combination is estimated to result in 3.6 fold increase in the amount of degraded crude oil.

Many researchers had shown that as the concentration of hydrocarbon increases, the rate of degradation decreases. For examples; a study by Rahman et al. (2002) showed the percentage of Bombay High (BH) crude oil degradation by the mixed bacterial consortium decreased from 78 to $52 \%$ as the concentration of crude oil was increased from 1 to $10 \%$. Sathishkumar et al. (2008) also found the percentage of degradation of crude oil by the mixed bacterial consortium decreased from 77 to $45 \%$ as the concentration of crude oil was increased from 1 to $12 \%$ at incubation temperature of $35^{\circ} \mathrm{C}$ and $\mathrm{pH} 7$. The used of mixed cultures which produced varieties of enzymes with synergistic interactions increase the rate of petroleum degradation.

This study showed optimization of parameters by RSM is a practical mathematical and statistical tool for analysing the effects of several independent variables on a process which is more reliable and time-saving compared to one to one factor method (Mohajeri et al. 2010; Zahed et al. 2010). RSM can also be used effectively for modelling and optimizing biodegradation of crude oil any environmental condition.

\section{CONCLUSION}

RSM was successfully used in this study to determine the optimum crude oil concentration and duration of incubation for optimal biodegradation of Tapis crude oil by consortium of bacteria and fungi. Duration of incubation was found to play a significant role in affecting the bacterial growth and TPH degradation. Bacterial and fungal growth, as well as TPH biodegradation were found to be affected significantly by the interaction between crude oil concentration and duration of incubation. Using the software-based optimization tool, simultaneous good bacterial and fungal growths were obtained, resulting in $86.46 \%$ biodegradation of $5 \%(\mathrm{v} / \mathrm{v})$ Tapis crude oil.

\section{REFERENCES}

Adebusoye, S.A., Ilori, M.O., Amund, O.O., Teniola, O.D. \& Olatope, S.O. 2007. Microbial degradation of petroleum hydrocarbons in a polluted tropical stream. World Journal of Microbiology and Biotechnology 23(8): 1149-1159.

Agarry, S.E., Owabor, C.N. \& Yusuf, R.O. 2012. Enhanced bioremediation of soil artificially contaminated with kerosene: Optimization of biostimulation agents through statistical experimental design. Journal of Petroleum \& Environmental Biotechnology 3(3): 2-8.

Ainon Hamzah, Chia-Wei Phan, Pek-Hoon Yong \& Nurul Hayati Mohd Ridzuan. 2014. Oil palm empty fruit bunch and sugarcane bagasse enhance the bioremediation of soil artificially polluted by crude oil. Soil and Sediment Contamination: An International Journal 23(7): 751-762.

Ainon Hamzah, Chia-Wei Phan, Nur Faizah Abu Bakar \& KokKee Wong. 2013. Biodegradation of crude oil by constructed bacterial consortia and the constituent single bacteria isolated from Malaysia. Bioremediation Journal 17(1): 1-10.

Ainon Hamzah, Mazni Abu Zarin, Aidil Abdul Hamid, Othman Omar \& Sahidan Senafi. 2012. Optimal physical and nutrient parameters for growth of Trichoderma virens UKMP-1M for heavy crude oil degradation. Sains Malaysiana 41(1): 71-79.

Ainon Hamzah, Amir Rabu, Raja Farzarul Hanim Raja Azmy \& Noor Aini Yussoff. 2010. Isolation and characterization of bacteria degrading Sumandak and South Angsi Oils. Sains Malaysiana 39(2):161-168.

Bao, M.T., Wang, L.N., Sun, P.Y., Cao, L.X., Zou, J. \& Li, Y.M. 2012. Biodegradation of crude oil using an efficient microbial consortium in a simulated marine environment. Marine Pollution Bulletin 64(6): 1177-1185.

Bento, F.M., Camargo, F.A.O., Okeke, B.C. \& Frankenberger, W.T. 2005. Comparative biodegradation of soil contaminated with diesel oil by natural attenuation, biostimulation and bioaugmentation. Resource Technology 96: 1049-1055.

Brooijmans, R.J.W., Pastink, M.I. \& Siezen, R.J. 2009. Hydrocarbon-degrading bacteria: The oil-spill clean-up crew. Microbial Biotechnology 2(6): 587-594.

Chaillan, F., Le Flèche, A., Bury, E., Phantavong, Y.H., Grimont, P., Saliot, A. \& Oudot, J. 2004. Identification and 
biodegradation potential of tropical aerobic hydrocarbondegrading microorganisms. Research in Microbiology 155(7): 587-595.

Changyi, Z., Qingyuan, L. \& Guocheng, S. 2009. Isolation, characterization and study on properties of a strain for degradation of offshore petroleum hydrocarbons. Journal of Jimei University 14(1): 24-28.

Das, N. \& Chandran, P. 2011. Microbial degradation of petroleum hydrocarbon contaminants: An overview. Biotechnology Research International 2011: 1-13.

Ghazali, F.M., Rahman, R.N.Z., Salleh, A.B. \& Basri, M. 2004. Biodegradation of hydrocarbons in soil by microbial consortium. International Biodeterioration \& Biodegradation 54: 61-67.

Haines, J.R., Koran, K.M., Holder, E.L. \& Venosa, A.D. 2003. Protocol for laboratory testing of crude-oil bioremediation products in freshwater conditions. Journal Indian Microbiology Biotechnology 30: 107-113.

Ijaha, U.J.J. \& Antaib, S.P. 2013. Removal of Nigerian light crude oil in soil over 12-month period. International Biodeterioration Biodegradation 51: 93-99.

Mitsika, E.E., Christophoridis, C. \& Fytianos, K. 2013. Fenton and Fenton-like oxidation of pesticide acetamiprid in water samples: Kinetic study of the degradation and optimization using response surface methodology. Chemosphere 93(9): 1818-1825.

Mohajeri, L., Aziz, H.A., Zahed, M.A., Mohajeri, S., Kutty, S.R.M. \& Isa, M.H. 2011. Response surface analysis and modeling of n-alkanes removal through bioremediation of weathered crude oil. Water Science and Technology 63(4): 618-626.

Mohajeri, L., Aziz, H.A., Isa, M.H. \& Zahed, M.A. 2010. A statistical experiment design approach for optimizing biodegradation of weathered crude oil in coastal sediments. Bioresource Technology 101(3): 893-900.

Moneke, A. \& Nwangwu, C. 2011. Studies on the bioutilization of some petroleum hydrocarbons by single and mixed cultures of some bacterial species. African Journal of Microbiology Research 5(12): 1457-1466.

Muthuswamy, S., Binupriya, A.R., Baik, S. \& Yun, S. 2008. Biodegradation of crude oil by individual bacterial strains and a mixed bacterial consortium isolated from hydrocarbon contaminated areas. Clean 36(1): 92-96.
Rahman, K.S.M.,Thahira-Rahman, J., Lakshmanaperumalsamy, P. \& Banat, I.M. 2002. Towards efficient crude oil degradation by a mixed bacterial consortium. Bioresource Technology 85: 257-261.

Sathishkumar, M., Binupriya, A.R., Baik, S. \& Yun, S. 2008. Biodegradation of crude oil by individual bacterial strains and a mixed bacterial consortium isolated from hydrocarbon contaminated areas. Clean 36: 92-96.

Sharma, S.L. \& Pant, A. 2001. Crude oil degradation by marine actinomycete Rhodococcus sp. Indian Journal of Marine Sciences 30: 146-150.

Sharma, A. \& Rehman, M.B. 2009. Laboratory scale bioremediation of diesel hydrocarbon in soil by indigenous bacterial consortium. Indian Journal of Experimental Biology 47: 766-769.

Thenmozhi, R., Nagasthya, A. \& Thajuddin, N. 2011. Studies on biodegradation of used engine oil by consortium cultures . Advances in Environmental Biology 5(6): 1051-1057.

Throne-Holst, M., Wentzel, A., Ellingsen, T.E., Kotlar, H.K. \& Zotchev, S.B. 2007. Identification of novel genes involved in long-chain n-alkane degradation by Acinetobacter sp. strain DSM 17874. Applied and Environmental Microbiology 73(10): 3327-3332

Zahed, M.A., Aziz, H.A., Isa, M.H. \& Mohajeri, L. 2010 Enhancement biodegradation of n-alkanes from crude oil contaminated seawater. International Journal of Environmental Research 4(4): 655-664.

School of Biosciences and Biotechnology

Faculty of Science and Technology

Universiti Kebangsaan Malaysia

43600 UKM, Bangi, Selangor Darul Ehsan

Malaysia

*Corresponding author; email: antara@ukm.edu.my

Received: 2 April 2015

Accepted: 14 April 2016 